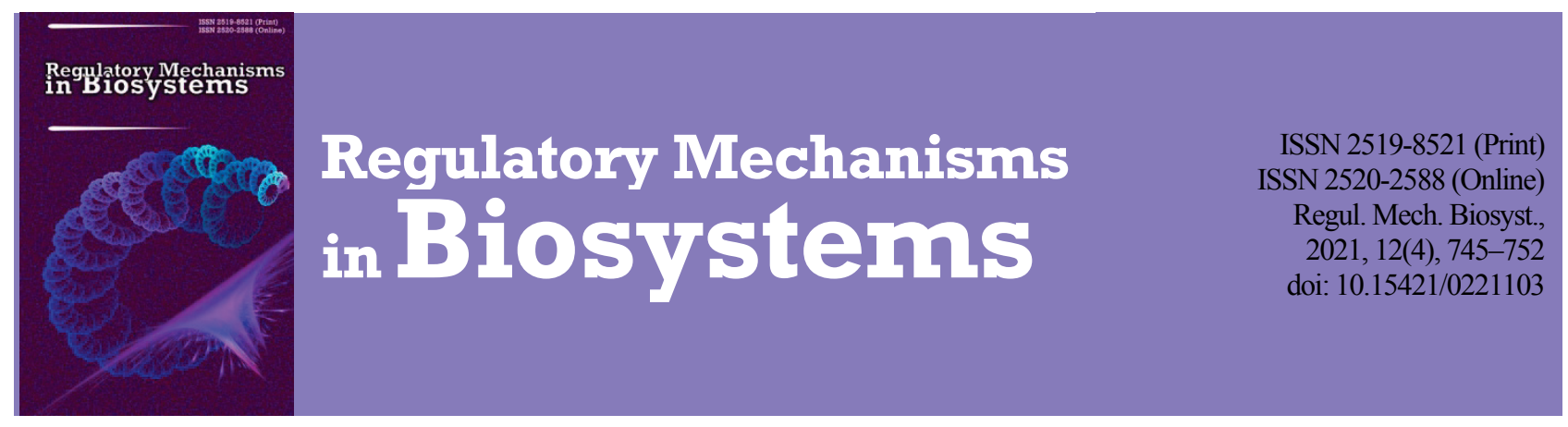

\title{
Influence of heavy metals on physiological and biochemical parameters of Pseudorasbora parva (Cypriniformes, Cyprinidae)
}

\author{
O. M. Marenkov*, O. O. Izhboldina**, M. M. Nazarenko**, R. V. Mylostyvyi**, \\ O. M. Khramkova**, N. O. Kapshuk**, M. V. Prychepa***, O. S. Nesterenko* \\ *Oles Honchar Dnipro National University, Dnipro, Ukraine \\ **Dnipro State Agrarian and Economic University, Dnipro, Ukraine \\ ***Institute of Hydrobiology of National Academy of Science of Ukraine, Kyiv, Ukraine
}

Article info

Received 25.10.2021

Received in revised form 18.11.2021

Accepted 19.11.2021

Oles Honchar Dnipro National University, Gagarin av., 72 Dnipro, 49010, Ukraine. Tel.: + 38-066-512-29-44. E-mail:gidrobions@gmail.com

Dnipro State Agrarian and Economic University, Sergey Efremov st., 25 Diipro, 49000, Ukraine Tel.: +38-07-338-75-57. E-mail: izhboldinaalena@ gmail.com

Institute of Hydrobiology of National Academy of Science of Ukraine Geroiv Stalingrada av., 12 Kyiv, 04210, Ukraine. Tel.: +38-097-314-51-01. E-mail:prichepa1987@ukr:net

\begin{abstract}
Marenkov, O. M., Izhboldina, O. O., Nazarenko, M. M., Mylostyvyi, R. V., Khramkova, O. M., Kapshuk, N. O., Prychepa, M. V., \& Nesterenko, O. S. (2021). Influence of heavy metals on physiological and biochemical parameters of Pseudorasbora parva (Cypriniformes, Cyprinidae). Regulatory Mechanisms in Biosystems, 12(4), 745-752. doi:10.15421/0221103
\end{abstract}

\begin{abstract}
Anthropogenic load on aquatic ecosystems leads to increased inputs of heavy metals, which can have a toxic effect on aquatic organisms. Some of the most appropriate objects for research are short-cycle fish species. This article considers the results of studies on the adaptive reactions of the stone moroko Pseudorasbora parva (Temminck et Schlegel, 1846) to Mn, $\mathrm{Pb}$, Ni heavy metal ions, which exceeded the reference values in the reservoir by $1.7,1.5$ and 2.0 times, respectively. Changes in morphological parameters of the blood and histocytological pattern of the hepatopancreas of the experimental species under the influence of toxicants, as well as changes in biochemical parameters, were determined. It was noted that the influence of Mn caused pathological changes in the form of poikilocytosis. The morphometric parameters of erythrocytes (the cell area and the nuclear area) reached $67.48 \pm 0.67$ and $13.97 \pm 0.22 \mu \mathrm{m}^{2}$ respectively ( $4.0 \%$ and $13.8 \%$ less compared to the control). The influence of Ni resulted in an increased number of leukocytes and immature forms of erythrocytes. The area of erythrocytes was $0.9 \%$ smaller than that of the control group, and the area of the nucleus was $4.5 \%$ smaller than in the control. The effect of $\mathrm{Pb}$ as well as Mn consisted in poikilocytosis. The area of red blood cells and nuclei was smaller by $6.5 \%$ and $8.3 \%$, respectively, compared to the control. The percentage of white blood cells in fish exposed to $\mathrm{Ni}$ and $\mathrm{Pb}$ tended to increase. In the experiment with nickel, the percentage of white blood cells was $10.2 \%$ of the number of formed elements; in the experiment with lead $-11.3 \%$; with manganese $-6.1 \%$, while in the control, the number of white blood cells compared to the total number of formed elements of fish was only $1.2 \%$. Cytometric studies have revealed that there are significant differences in the shape, size, and location of hepatocytes in different experimental fish. The structural components of the liver for histological specimens were stained differentially with different intensities and different colours. The hepatocytes on histological specimens of the liver of the stone moroko exposed to Ni and Mn ions did not have clearly defined boundaries, there was a large number of destroyed cells, which indicates the toxic effect of these heavy metals. The hepatocytes exposed to $\mathrm{Pb}$ had the largest area of cells and nuclei and the highest nuclear-cytoplasmic ratio is typical for hepatocytes under the influence of $\mathrm{Mn}$. The nuclei had the largest size and occupied $12.7 \%$ of the internal contents of the cells. It is shown that under the impact of the studied concentrations of $\mathrm{Mn}, \mathrm{Ni}$ and $\mathrm{Pb}$, lactate dehydrogenase activity increased by $1.22,1.14$ and 1.48 times compared to the control, respectively. In contrast, there was a 3.27-fold decrease in succinate dehydrogenase activity under the impact of Mn. Besides that, the activity of the enzyme decreased by 1.48 and 1.68 times under the action of $\mathrm{Ni}$ and $\mathrm{Pb}$. Subsequently, we found an increase in the activity of alkaline phosphatase in muscle tissue by 3.25-3.94 times under the influence of the studied toxicants. Muscle protein levels under the impact of Mn were 1.14 times lower than in the control, the most distinct decrease in protein was found under the impact of $\mathrm{Ni}$ (1.53 times). The obtained data of physiological and biochemical reactions of the stone moroko to the influence of heavy metals provide an opportunity to predict changes in the species composition of fish fauna under conditions of excessive toxic pollution of ecosystems.
\end{abstract}

Keywords: adaptive reactions; formed elements; enzyme activity; nickel; manganese; lead.

\section{Introduction}

Currently, one of the most important problems is the emergence of invasive species and their assimilation into water bodies of different types. This problem becomes global due to the significant adaptive capabilities of these species to occupy new territories, which negatively affects local species (Britton, 2005; Hardouin et al., 2018). Nowadays, fragmentation of biotopes, eutrophication, active silting of the channel of water bodies, and toxic pollution affect hydrobionts. In such an anthropogenic environment, fish species with a high level of ecological plasticity become dominant. This is noticeable in water bodies with no competition and predation on the part of native representatives of the fish fauna: artificial reservoirs, lakes, fish ponds. This may have a significant impact on the indicators of biological productivity and biological diversity in ecosystems in the future (Záhorská \& Kováć, 2009) Therefore, study of the adaptive features of invasive fish species is an urgent issue for understanding the potential consequences of their subsequent invasion. One of the most successful examples of naturalization is stone moroko Pseudorasbora parva (Temminck et Schlegel, 1846). The species is characterized by some important ecological and physiological features that allow it to respond quickly and adequately to changes in the environment (Copp \& Gozlan, 2010; Kovalenko et al., 2021). It is known that the stone moroko is one of the best examples of the accidental introduction into the water bodies of Europe. The natural range of this species is North - West Asia (Amur Basin, Korea, Northern and Central China, Taiwan) (Pollux \& Korosi, 2006). The study of this species in unstable ecological conditions is of great inte- 
rest, under the conditions of toxic pollution, using for research several important physiological and biochemical parameters that could reflect the adaptation processes of this species. Due to the features of physiological and behavioural reactions, the species can actively counteract toxic effects, surviving even in extreme conditions. Even though the stone moroko is a short-cycle fish, the species actively changes generations by batch spawning, quickly renewing the population, and forming highly resistant groups.

Now many countries of the world face the problem of the pollution of the water and land environment with toxicants of various chemical nature. Ukraine is not an exception. One of the centres of anthropogenic pollution in Ukraine is the Dnipro region, where industry significantly impacts the state of the environment. The basin of the Dnipro (Zaporizhzhia) Reservoir is located in the territory of industrial zones, and thus it is under a stable anthropogenic load (Sharamok et al., 2017). Priority toxicants of the reservoir are heavy metals that come with industrial wastewater, atmospheric precipitation and are delivered with the water of the Dnipro tributaries. They affect the water quality, contaminating bottom sediments, which under certain conditions can become a source of secondary contamination of water masses with heavy metals. Given their ability to move from one chemical state to another and the features of their migration in trophic links, they can cause irreversible changes in organisms. This affects not only the organism but also the groups of different animal taxa (Farombi et al., 2007). Fish can accumulate heavy metals via the gills and skin or by ingesting contaminated food through the digestive tract (Demirak et al., 2006; Sfankianakis et al., 2015).

Considering the fact that the stone moroko has actively naturalized in the Dnipro region, it remains relevant to study the problem of physiological and biochemical reactions of this species to adapt to conditions of toxic load, because the limits of endurance of the species are manifested under such conditions. Therefore, the work aimed to study the toxic effect of the most common priority heavy metals on the physiological and biochemical parameters of stone moroko, an invasive species of the water bodies of the Prydniprovia region.

\section{Materials and methods}

All laboratory animals were kept and examined under the Guide for the Care and Use of Laboratory Animals and Regulations on the Ethics Committee (Guide for the Care and Use of Laboratory Animals, 2011).

In the experiment 60 fingerlings of the stone moroko $P$. parva (Temminck et Schlegel, 1846) were used. The fish were divided into four groups $(\mathrm{n}=15)$. The first group was a control group; the second was a group with the addition of $\mathrm{Ni}\left(\mathrm{NO}_{3}\right)_{2} \times 6 \mathrm{H}_{2} \mathrm{O}$ (Sigma, USA); the third group was with $\mathrm{Pb}\left(\mathrm{NO}_{3}\right)_{2}$, (Sigma, USA); the fourth group was with $\mathrm{MnSO}_{4} \times 5 \mathrm{H}_{2} \mathrm{O}$ (Sigma, USA). The water in the aquariums was completely changed twice a week with the addition of experimental substances based on the concentration of heavy metal ions: $\mathrm{Ni}^{2+}-0.04 \mathrm{mg} / \mathrm{L}$ (4 MAC ), $\mathrm{Pb}^{2+}-0.15 \mathrm{mg} / \mathrm{L}$ (1.5 MAC), $\mathrm{Mn}^{2+}-0.02 \mathrm{mg} / \mathrm{L}$ (2 MAC). The concentration of toxic compounds, in particular heavy metals, was selected according to their content in the water of the Dnieper (Zaporizhzhia) Reservoir, the recipient water body for this species. The constant water temperature in aquariums was maintained by a thermostat and it was $+22^{\circ} \mathrm{C}$. The oxygen regime was maintained by a Tetratec APS 300 compressor (Germany), the oxygen content in the aquarium water was 6 $7 \mathrm{mgO}_{2} / \mathrm{dm}^{3}$. The fish were fed the same amount of food every day. The experiment lasted 21 days and was conducted following the "Regulation on the use of animals in biomedical experiments" (Regulation on the use of animals ..., 2003).

Liver for histological studies was obtained from the fish by anatomical dissection. Fragments of organs measuring $0.3-0.5 \mathrm{~cm}$ were selected for fixation. For the production of histological specimens, liver tissues were stained with hematoxylin and eosin. Photos of histological preparations were taken using a digital camera which was connected to a microscope. Histological sections were examined with a microscope at 40x magnification using microphotography with a "Sciencelab T500 5.17 m" digital camera (Br-tools, Ukraine, 2017). During the experiment, the effect of heavy metal concentrations on hematological parameters and the cytogenetic stability of red blood cells was studied. Blood was taken from the fish with a Pasteur pipette from the heart. Smears were prepared imme- diately after blood sampling, air-dried, and fixed in methanol for $5 \mathrm{mi}$ nutes. Fish blood smears were stained according to Pappenheim (Davydov et al., 2006). They were stained with $0.3 \%$ May-Grunwald solution for ten minutes, 4 parts of phosphate buffer ( $\mathrm{pH} 6.8-7.2)$ were added to 1 part of it. After, they were treated with Romanowsky stain solution for 30-40 minutes. After staining, the preparations were thoroughly washed with distilled water and placed vertically on filter paper to dry. The further analysis involved determining the morphological composition of blood using a MicroMed-2 optical immersion microscope (MICROmed, Ukraine, 2018). Blood cells were identified using atlases (Ivanova, 1983; Fánge, 1992). Pathological forms of cells were determined according to Zhiteneva et al. (1989).

The muscle tissue of stone moroko was used to determine the effect of heavy metals on the viability and activity of metabolic processes. Muscle tissue $(200 \mathrm{mg})$ was homogenized in $0.2 \mathrm{~m} \mathrm{KCl}(5 \mathrm{~mL})$ in a homogenizer. The homogenate was then centrifuged at $3000 \mathrm{rpm}$ for 15 minutes. Succinate dehydrogenase (SDH) activity was measured on a Unico 2800 spectrophotometer (United Products and Instruments, USA, 2020) at a wavelength of $420 \mathrm{~nm}$ (Eschenko \& Volskiy, 1982). Lactate dehydrogenase (LDH) activity was measured using standard "LDH" kits (Filisit diagnostics, Ukraine, 2020) (Putilina \& Zoidze, 1982) on a Unico 2800 spectrophotometer (United Products and Instruments, USA, 2020) at a wavelength of $340 \mathrm{~nm}$. The activity of alkaline phosphatase (LP) was evaluated using an "LP" set of reagents ("Filisit diagnostics", Ukraine, 2020). Total protein in muscle tissue was determined on a KFK-2M photocolorimeter (MICROmed, Ukraine, 2019) at a wavelength of $750 \mathrm{~nm}$ using the Lowry method (Lowry et al., 1951).

The data was processed using Statistica 8.0 personal computer software packages (StatSoftInc, USA). All data are presented as the arithmetic mean of the sample and standard error. The difference between the control and experimental groups was considered significant if the significance level was at the level of $\mathrm{P}<0.05$ (considering the Bonferroni correction).

\section{Results}

Linear and weight indicators of fish. In the experimental aquarium with $\mathrm{Ni}$, the average fish weight was $1.06 \pm 0.12 \mathrm{~g}$; $\mathrm{Pb}-0.82 \pm 0.09 \mathrm{~g}$; $\mathrm{Mn}-0.98 \pm 0.13 \mathrm{~g}$, and in the control aquarium $-0.97 \pm 0.16 \mathrm{~g}$. During the experiment, one individual died in the aquarium with Ni on Day 2 and another one on Day 6. In the experiment with $\mathrm{Pb}$, two individuals also died on the 3rd and 5th days of the experiment. In the aquarium with $\mathrm{Mn}$, three individuals died on Days 2, 6 and 11. On the 14th day of the experiment, one individual died in the control aquarium. We have noticed that the effect of toxic substances changed fish behaviour. There was an inhibition of motor activity, a decrease in reflex reactions, compared to the control for 2 days, after which the fish adapted to toxicants.

The evaluation of the growth indicators of fish after the experiment has shown that their mass in the experimental aquarium increased by $10.3 \%$. In the aquarium with $\mathrm{Ni}$, the mass of individuals increased by $4.7 \%$; in the aquarium with $\mathrm{Pb}$, the total weight decreased by $7.8 \%$; in the experimental aquarium with $\mathrm{Mn}$, the mass increased by $2.0 \%$ (Table 1 ).

\section{Table 1}

Indicators of the mass, the industrial and total length of individuals at the end of 21 days of the experiment on the effect of heavy metals added to water in the form of metal salts on the fish body

\begin{tabular}{lcccc}
\hline \multicolumn{1}{c}{ Indicator name } & $\begin{array}{c}\text { Control } \\
(\mathrm{n}=14)\end{array}$ & $\begin{array}{c}\mathrm{Ni} \\
(\mathrm{n}=13)\end{array}$ & $\begin{array}{c}\mathrm{Pb} \\
(\mathrm{n}=13)\end{array}$ & $\begin{array}{c}\mathrm{Mn} \\
(\mathrm{n}=12)\end{array}$ \\
\hline $\mathrm{L}_{1}, \mathrm{~cm}$ & $4.00 \pm 1.75$ & $4.25 \pm 0.12$ & $3.83 \pm 0.16$ & $3.90 \pm 0.32$ \\
$\mathrm{~L}_{2}, \mathrm{~cm}$ & $4.70 \pm 0.58$ & $5.13 \pm 0.10$ & $4.53 \pm 0.18$ & $4.73 \pm 0.40$ \\
Length change, $\mathrm{cm}$ & +0.70 & +0.88 & +0.70 & +0.83 \\
$\mathrm{~m}_{1}, \mathrm{~g}$ & $0.87 \pm 0.53$ & $1.01 \pm 0.19$ & $0.89 \pm 0.34$ & $0.96 \pm 0.19$ \\
$\mathrm{~m}_{2}, \mathrm{~g}$ & $0.97 \pm 0.16$ & $1.06 \pm 0.12$ & $0.82 \pm 0.09$ & $0.98 \pm 0.13$ \\
Mass change, $\mathrm{g}$ & +0.10 & +0.05 & -0.07 & +0.02 \\
\hline
\end{tabular}

Note: according to the results of multivariate analysis, considering the Bonferroni correction, no differences were found among all samples; $\mathrm{L}_{1}$ - the initial length of the fish at the beginning of the experiment, $\mathrm{L}_{2}-$ the final length of the fish after the completion of the experiment, $\mathrm{m}_{1}$ - the initial mass of fish at the beginning of the experiment, $\mathrm{m}_{2}-$ the final mass after the completion of the experiment; $\mathrm{x} \pm \mathrm{SE}$. 
Cytomorphological analysis of blood cells of the stone moroko under the influence of heavy metals. On the blood specimens of the control group of fish that were in optimal aquatic conditions, red blood cells had a normal ovoid shape with clear contours, the cytoplasm was oxyphilic, the nucleus was dark purple, ovoid, located in the centre of the cell (Fig. 2). The area of red blood cells in the control ranged from a minimum of $32.42 \mu \mathrm{m}^{2}$ up to a maximum of $98.37 \mu \mathrm{m}^{2}$ and averaged $70.3 \pm 0.95 \mu \mathrm{m}^{2}$.

In the experimental group of fish exposed to $\mathrm{Mn}$, pathological changes in red blood cells were noted. There were red blood cells with an irregular form. The cytomorphological analysis of red blood cells showed that the most common pathological change in red blood cells under the influence of $\mathrm{Mn}$ was poikilocytosis, changes in the shape of red blood cells of varying degrees beyond the norm. Usually, poikilocytosis develops in fish anemia. The pathological form of red blood cells with appendages, which is typical for the inhibition of erythropoiesis, was sometimes found in the field of vision. In addition, there were shifts of nuclei in some cells (Fig. 1).

The cytometric studies revealed that the area of red blood cells of experimental fish in the experiment with manganese reached $67.48 \pm 0.67 \mu \mathrm{m}^{2}$, which is $4.0 \%$ less than in the control. The area of the red blood cell nucleus of experimental fish reached $13.97 \pm 0.22 \mu \mathrm{m}^{2}$. In the control, it was $16.20 \pm 0.25 \mu \mathrm{m}^{2}$, that is, in the experiment, the result was $13.8 \%$ less than in the control. The average large diameter of red blood cells was $10.51 \pm$ $0.66 \mu \mathrm{m}^{2}$ in the experiment, which is $9.6 \%$ less than the control ones.
The cytometric studies showed that the area of red blood cells of experimental fish in the experiment with manganese reached $67.48 \pm$ $0.67 \mu \mathrm{m}^{2}$, that is $4.0 \%$ less than that of the control indicators, while the difference in small diameters between the red blood cells of the experiment and the control was $15.4 \%$ (Table 2).

\section{Table 2}

Changes in morphometric parameters of fish blood cells due to the effect of Mn added in the form of manganese salts to the water of an experimental aquarium

\begin{tabular}{lcc}
\hline \multicolumn{1}{c}{ Indicator } & $\begin{array}{c}\text { Control } \\
(\mathrm{n}=100)\end{array}$ & $\begin{array}{c}\text { Experiment with } \mathrm{Mn} \\
(\mathrm{n}=100)\end{array}$ \\
\hline $\mathrm{S}, \mu \mathrm{m}^{2}$ & $70.30 \pm 0.95$ & $67.48 \pm 0.67^{*}$ \\
$\mathrm{~S}, \mu \mathrm{m}^{2}$ & $16.20 \pm 0.25$ & $13.97 \pm 0.22^{* * *}$ \\
$\mathrm{D}, \mu \mathrm{m}^{2}$ & $11.63 \pm 0.11$ & $10.51 \pm 0.66$ \\
$\mathrm{~d}, \mu \mathrm{m}^{2}$ & $7.66 \pm 0.14$ & $9.05 \pm 0.20^{* * *}$ \\
\hline
\end{tabular}

Note: * - the difference is significant at $\mathrm{P}<0.05,{ }^{* *}$ - the difference is significant at $\mathrm{P}$ $<0.01, * * *$ - the difference is significant at $\mathrm{P}<0.001, \mathrm{~S}-$ the cell area, $\mathrm{S}-$ the nucleus area, $\mathrm{D}$ - the large cell diameter, $\mathrm{d}$ - the small cell diameter; $\mathrm{x} \pm \mathrm{SE}$.

In the experiment with $\mathrm{Ni}$, immature forms of red blood cells and an increased number of white blood cells were found on the specimen. There also was a nuclear shift in some cells, but in most cases, red blood cells had clear borders, an oval shape, and a single nucleus (Fig. 2).

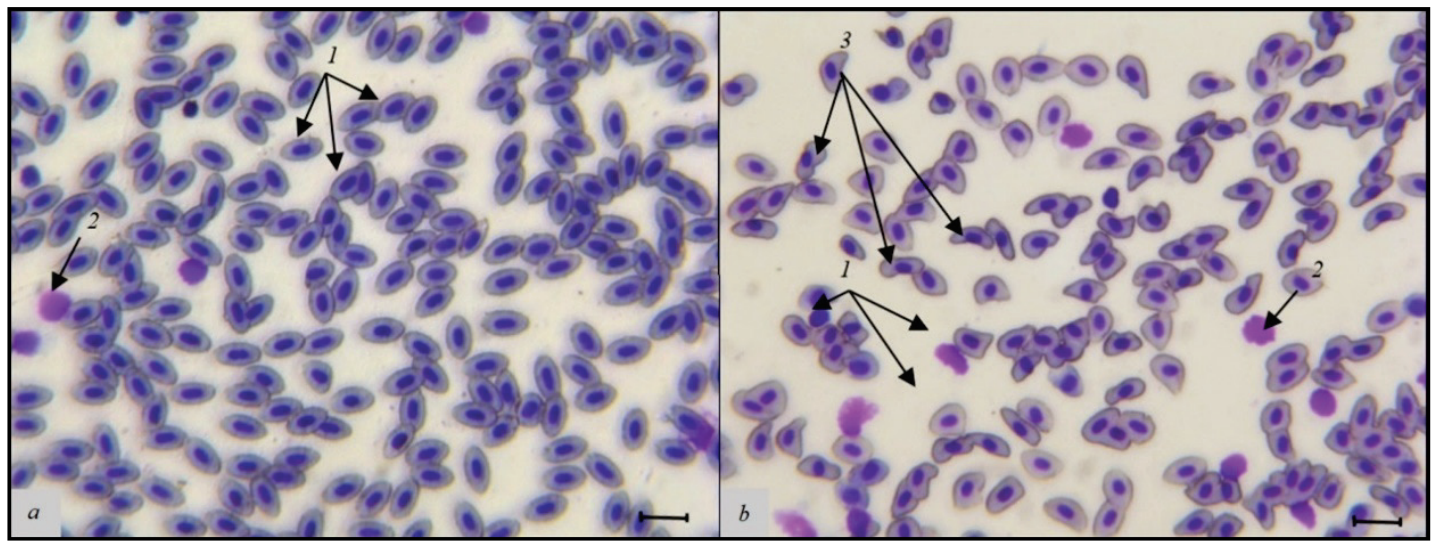

Fig. 1. The smear of blood cells: $a$-control, $b$ - experiment with Mn; 1 -red blood cells, the erythrocytes; 2 - white blood cells; 3 - poikilocytosis; bar-10 $\mu \mathrm{m}$

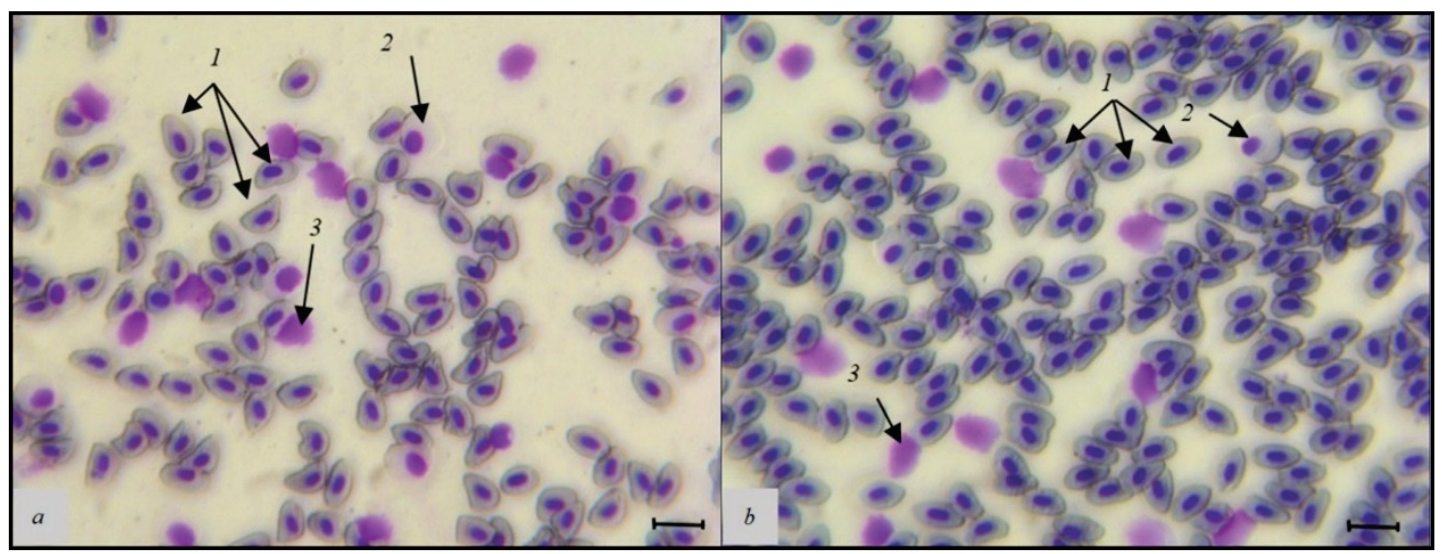

Fig. 2. The smear of blood cells: $a$-experiment with $\mathrm{Pb}, b$-experiment with $\mathrm{Ni}$;

1 -red blood cells, the erythrocytes; 2 -immature red blood cells; 3 - white blood cells; bar - $10 \mu \mathrm{m}$

In the experimental group with $\mathrm{Ni}$, the area of red blood cells was $0.9 \%$ smaller than in the control group. The area of the red blood cell nucleus was $15.47 \pm 0.26 \mu \mathrm{m}^{2}$, which is $4.5 \%$ less than the control result. The large diameter of red blood cells was $13.00 \pm 0.63 \mu \mathrm{m}^{2}$ in the experiment and $11.63 \pm 0.11 \mu \mathrm{m}^{2}$ in the control. The difference between the control and the experiment was $10.5 \%$, and the small diameters of the red blood cells of the experiment group were $9.0 \%$ greater than in the control (Table 3). The red blood cells of irregular form were observed among the blood cells of stone moroko exposed to $\mathrm{Pb}$. There were pear-shaped, sickle-shaped and diamond-shaped cells. The observed pathological changes in cells are the same as those observed in the experimental group under the influence of Mn. The analysis of red blood cells showed that the most common pathological change in red blood cells is also poikilocytosis.

According to the research results, the average area of red blood cells in the $\mathrm{Pb}$ experiment averaged $65.7 \pm 0.93 \mu \mathrm{m}^{2}$ which is $6.5 \%$ less than the area of red blood cells in the control. The area of the red blood cell 
nucleus was $14.86 \pm 0.25 \mu^{2}$ in the experiment, which is $8.3 \%$ less than the control result. The large diameter of red blood cells in the experiment with lead was $3.8 \%$ greater than in the control while the small diameter of red blood cells in the control was $10.7 \%$ larger than in the experiment (Table 4).

Table 3

Changes in morphometric parameters of fish blood cells due to the effect of $\mathrm{Ni}$ added in the form of nickel salts to the water of an experimental aquarium

\begin{tabular}{lcc}
\hline \multicolumn{1}{c}{ Indicator } & $\begin{array}{c}\text { Control } \\
(\mathrm{n}=100)\end{array}$ & $\begin{array}{c}\text { Experiment with Ni } \\
(\mathrm{n}=100)\end{array}$ \\
\hline $\mathrm{S}, \mu \mathrm{m}^{2}$ & $70.30 \pm 0.95$ & $69.70 \pm 0.70$ \\
$\mathrm{~S}, \mu \mathrm{m}^{2}$ & $16.20 \pm 0.25$ & $15.47 \pm 0.26^{*}$ \\
$\mathrm{D}, \mu \mathrm{m}^{2}$ & $11.63 \pm 0.11$ & $13.00 \pm 0.63^{*}$ \\
$\mathrm{~d}, \mu \mathrm{m}^{2}$ & $7.66 \pm 0.14$ & $6.97 \pm 0.99$ \\
\hline
\end{tabular}

Note: * - the difference is significant at $\mathrm{P}<0.05, \mathrm{~S}-$ the cell area, $\mathrm{s}-$ the nucleus area, $\mathrm{D}$ - the large cell diameter, $\mathrm{d}-$ the small cell diameter, $\mathrm{x} \pm \mathrm{SE}$.

Table 4

Changes in morphometric parameters of fish blood cells due to the effect of $\mathrm{Pb}$ added in the form of nickel salts to the water of an experimental aquarium

\begin{tabular}{lcc}
\hline \multicolumn{1}{c}{ Indicator } & $\begin{array}{c}\text { Control } \\
(\mathrm{n}=100)\end{array}$ & $\begin{array}{c}\text { Experiment with } \mathrm{Pb} \\
(\mathrm{n}=100)\end{array}$ \\
\hline $\mathrm{S}, \mu \mathrm{m}^{2}$ & $70.30 \pm 0.95$ & $65.70 \pm 0.93^{* * *}$ \\
$\mathrm{~S}, \mu \mathrm{m}^{2}$ & $16.20 \pm 0.25$ & $14.86 \pm 0.25^{* * *}$ \\
$\mathrm{D}, \mu \mathrm{m}^{2}$ & $11.63 \pm 0.11$ & $12.10 \pm 0.16^{*}$ \\
$\mathrm{~d}, \mu \mathrm{m}^{2}$ & $7.66 \pm 0.14$ & $6.84 \pm 0.07^{* * *}$ \\
\hline
\end{tabular}

Note: $*$ - the difference is significant at $\mathrm{P}<0.05$, *** - the difference is significant at $\mathrm{P}<0.001, \mathrm{~S}-$ the cell area, $\mathrm{s}-$ the nucleus area, $\mathrm{D}-$ the large cell diameter, $\mathrm{d}-$ the small cell diameter; $\mathrm{x} \pm \mathrm{SE}$.

It is worth mentioning that there was a tendency to increase in the percentage of white blood cells in fish exposed to $\mathrm{Ni}$ and $\mathrm{Pb}$. In the experiment with nickel, the percentage of white blood cells was $10.2 \%$ of the number of the formed elements; in the experiment with lead $-11.3 \%$; with manganese $-6.1 \%$, while in the control group, the number of white blood cells compared to the total number of the formed elements of fish was only $1.2 \%$. Leukocytosis may indicate pathologies associated with inflammatory processes, the immune system response to foreign substances, and disorders of the hematopoietic organs.

Histological pattern of the hepatopancreas of stone moroko. In the control, the liver tissue of stone moroko was pink, the nuclei of hepatocytes were stained with varying intensity from light blue to dark blue. Hepatocytes had a regular polygonal shape, a single nucleus with a welldefined nucleolus (Fig. 3). The results of histometric studies have revealed that the area of liver hepatocyte cells in the control group ranged from a minimum of $77.75 \mu \mathrm{m}^{2}$ up to a maximum of $206.86 \mu \mathrm{m}^{2}$ and averaged $124.32 \pm 4.10 \mu \mathrm{m}^{2}$.

In the experiment with Mn, many destroyed liver cells and their nuclei were observed. On histological specimens, there were liver cells without clear membranes. There were also observed hepatocytes with an irregular shape. The nuclei of hepatocytes were smaller than in the control, and the nucleoli were poorly visible. In the hepatopancreas of stone moro- ko, some hepatocytes were dispersed in small groups of cells in different parts of the hepatic lobule.

According to the histometric data, the average area of liver lobules in the stone moroko yearlings in the experiment with Mn was $128.53 \pm$ $5.41 \mu \mathrm{m}^{2}$, which is $3.3 \%$ more than in the control. The area of the liver cell nucleus was equal to $16.33 \pm 0.39$, which is $13.6 \%$ greater than the control indicator. The nuclear-cytoplasmic ratio $(\mathrm{N}: \mathrm{C})$ of liver cells in the experiment with Mn was $12.7 \%$, while in the control it was $15.2 \%$ (Table 5).

Table 5

Changes in morphometric parameters of fish hepatocytes due to the effect of Mn added in the form of manganese salts to the water of an experimental aquarium

\begin{tabular}{lcc}
\hline \multicolumn{1}{c}{ Indicator } & $\begin{array}{c}\text { Control } \\
(\mathrm{n}=50)\end{array}$ & $\begin{array}{c}\text { Experiment with Mn } \\
(\mathrm{n}=50)\end{array}$ \\
\hline $\mathrm{S}, \mu \mathrm{m}^{2}$ & $124.32 \pm 4.10$ & $128.53 \pm 5.41$ \\
$\mathrm{~S}, \mu \mathrm{m}^{2}$ & $18.90 \pm 0.59$ & $16.33 \pm 0.39^{* * * *}$ \\
Nuclear-cytoplasmic ratio, $\%$ & 15.2 & 12.7 \\
\hline
\end{tabular}

Note: $* * *$ - the difference is significant at the probability level $\mathrm{P}<0.001, \mathrm{~S}$ - the cell area, $\mathrm{s}-$ the area of the nucleus; $\mathrm{x} \pm \mathrm{SE}$.

In the experiment with $\mathrm{Pb}$, histological studies of the liver showed that liver cells were not separated with connective tissue from each other, hepatocytes were snug against each other, hepatocyte nuclei had a rounded shape, and contained mainly one nucleolus. In some hepatocytes, the nuclei were displaced, since the great part of the cytoplasm was occupied by a fat drop. Most of the cells had the proper shape, but some hepatocytes did not have a clear form, which indicates a violation of their morphophysiological structure. The cell structure was almost completely disrupted on liver specimens of stone moroko exposed to simulated Ni salt concentrations, as well as in the experiment with $\mathrm{Mn}$. The photo of the hepatopancreas shows many destroyed cells and their nuclei. The shape of the liver cells was not clearly visible because the hepatocytes were destroyed. In some hepatocytes, the nuclei were displaced in the field of view. There were areas with single adipocytes replacing liver parenchyma cells (Fig. 4).

At the end of the experiment, it was noted that the area of hepatocytes in experimental fish in the experiment with $\mathrm{Pb}$ reached $215.12 \pm$ $7.71 \mu \mathrm{m}^{2}$, which is $42.2 \%$ more than in the control group (Table 6). The area of the liver cell nucleus was $19.70 \pm 0.61 \mu \mathrm{m}^{2}$, which is $4.0 \%$ more than in the control, where this indicator was equal to $18.09 \pm$ $0.59 \mu \mathrm{m}^{2}$. The nuclear-cytoplasmic ratio of liver cells under the influence of $\mathrm{Pb}$ reached $9.2 \%$, and it was $15.2 \%$ in the control.

\section{Table 6}

Changes in morphometric parameters of fish hepatocytes due to the effect of $\mathrm{Pb}$ added in the form of manganese salts to the water of an experimental aquarium

\begin{tabular}{lcc}
\hline \multicolumn{1}{c}{ Indicator } & Control & Experiment with \\
& $(\mathrm{n}=50)$ & $\mathrm{Pb}(\mathrm{n}=50)$ \\
\hline $\mathrm{S}, \mu \mathrm{m}^{2}$ & $124.32 \pm 4.10$ & $215.12 \pm 7.71^{* * * *}$ \\
$\mathrm{~S}, \mu \mathrm{m}^{2}$ & $18.90 \pm 0.59$ & $19.70 \pm 0.61$ \\
Nuclear-cytoplasmic ratio, $\%$ & 15.2 & 9.2 \\
\hline
\end{tabular}

Note: $* * *$ - the difference is significant at $(\mathrm{P}<0.001), \mathrm{S}-$ the cell area, $\mathrm{s}-$ the area of the nucleus; $\mathrm{x} \pm \mathrm{SE}$.

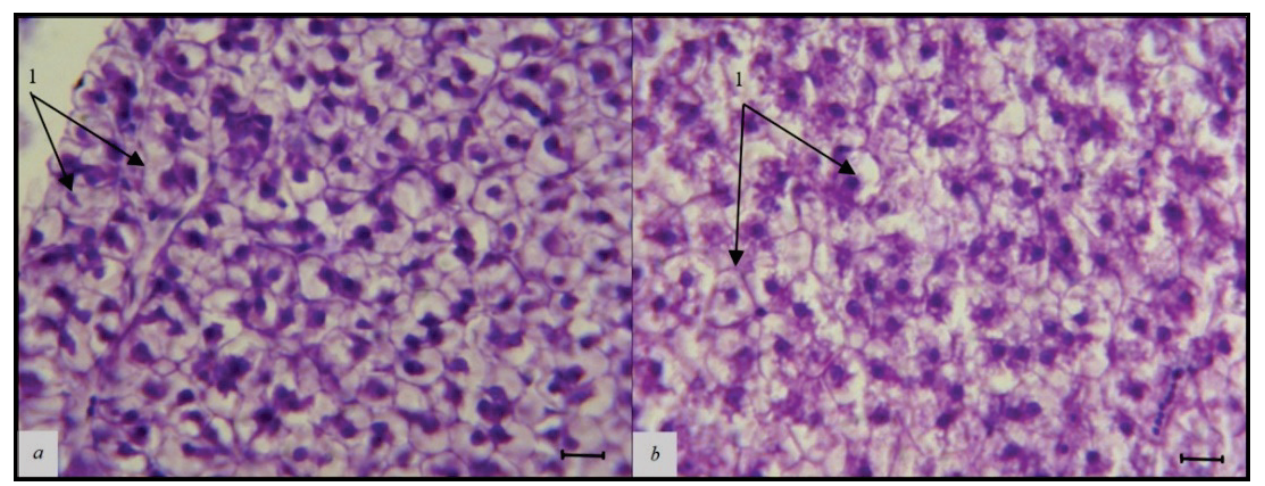

Fig. 3. Liver section: $a$-control, $b$ - experiment with Mn; hepatopancreas tissue, which consists of hepatocyte cells ( 1 ); bar $-10 \mu \mathrm{m}$ 


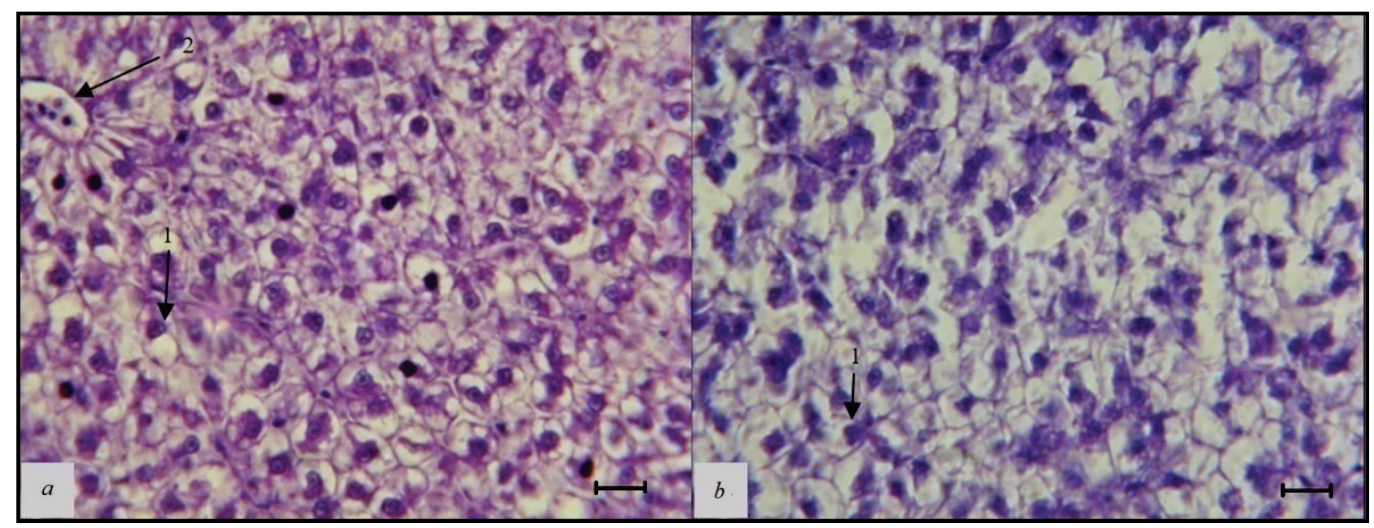

Fig. 4. Liver section: $a$-experiment with $\mathrm{Pb}, b$-experiment with $\mathrm{Ni}$;

hepatopancreas tissue, which consists of hepatocyte cells (1), blood vessels (2); bar $-10 \mu \mathrm{m}$

It has been determined that the area of hepatocytes of fish in the experiment with $\mathrm{Ni}$ was $169.53 \pm 4.35 \mu \mathrm{m}^{2}$, which is $26.7 \%$ more than in the control group. The area of the cell nucleus was $6.6 \%$ smaller than in the control and was equal to $17.65 \pm 0.5 \mu \mathrm{m}^{2}$. The nuclear-cytoplasmic ratio of liver cells under the influence of nickel was 10.4\% (Table 7).

\section{Table 7}

Changes in morphometric parameters of fish hepatocytes due to the effect of $\mathrm{Ni}$ added in the form of manganese salts to the water of an experimental aquarium

\begin{tabular}{lcc}
\hline \multicolumn{1}{c}{ Indicator } & $\begin{array}{c}\text { Control } \\
(\mathrm{n}=50)\end{array}$ & $\begin{array}{c}\text { Experiment with } \mathrm{Ni} \\
(\mathrm{n}=50)\end{array}$ \\
\hline $\mathrm{S}, \mu \mathrm{m}^{2}$ & $124.32 \pm 4.10$ & $169.53 \pm 4.35^{* * *}$ \\
$\mathrm{~S}, \mu \mathrm{m}^{2}$ & $18.90 \pm 0.59$ & $17.65 \pm 0.53$ \\
Nuclear-cytoplasmic ratio, \% & 15.2 & 10.4 \\
\hline
\end{tabular}

Note: $* * *$ - the difference is significant at $(\mathrm{P}<0.001), \mathrm{S}-$ the cell area, $\mathrm{s}-$ the area of the nucleus; $x \pm S E$.

The cytometric studies revealed that there were significant differences in the shape, size and location of hepatocytes in different experimental fish. The structural components of the liver for histologic specimens were stained differentially with different intensities and different colours. The hepatocytes on histologic specimens of the liver of the stone moroko exposed to $\mathrm{Ni}$ and $\mathrm{Mn}$ ions did not have clearly defined boundaries, there was a large number of destroyed cells, which indicates the toxic effect of these heavy metals. The hepatocytes exposed to $\mathrm{Pb}$ had the largest area of cells and nuclei and the highest nuclear-cytoplasmic ratio is typical for hepatocytes under the influence of $\mathrm{Mn}$. The nuclei had the largest size and occupied $12.7 \%$ of the internal contents of the cells.

Thus, histopathological analysis of hepatopancreas tissues of experimental fish showed that the toxic effect of heavy metal concentrations caused changes in the structure of hepatocytes of the stone moroko.

Effect of toxic compounds on the activity of energy and phosphate metabolism enzymes.

Under the impact of the studied concentrations of $\mathrm{Mn}, \mathrm{Ni}$ and $\mathrm{Pb}$, the lactate dehydrogenase activity increased by $1.22,1.14$ and 1.48 times compared to the control, respectively (Fig. 5). In contrast, there was a 3.27-fold decrease in succinate dehydrogenase activity under the impact of $\mathrm{Mn}$. Besides that, the activity of the enzyme decreased by 1.48 and 1.68 times under the influence of $\mathrm{Ni}$ and $\mathrm{Pb}$ (Fig. 6). Subsequently, we found an increase in the activity of alkaline phosphatase in muscle tissue by 3.25-3.94 times under the influence of the studied toxicants (Fig. 7). Muscle protein levels under the impact of Mn were 1.14 times lower than in the control, the most distinct decrease in protein was found under the impact of Ni (1.53 times) (Fig. 8).

\section{Discussion}

The study has shown that the presence of toxic heavy metals in the aquatic environment has a strong effect on hematological parameters in freshwater fish. It is well known that they affect hematological parameters by inhibiting the activity of several enzymes involved in heme biosynthe- sis. We have found that the studied metal concentrations affected the viability of the stone moroko fingerlings. The death of fish in the first days of the experiment in aquariums may indicate a negative and toxic effect of heavy metal salts. Heavy metals cause functional disorders in the tissues and organs of hydrobionts, affecting their linear and mass indicators, reproductive system, digestive, and excretory organs. No significant changes were found in linear and mass indicators. We have noticed that the effect of toxic substances changed fish behaviour. There was an inhibition of motor activity, a decrease in reflex reactions, compared to the control for 2 days, after which the fish adapted to toxicants. However, toxic exposure led to the death of some individuals, which indicates the presence of sensitive individuals in the study sample of fish. Heavy metals had a significant impact on hematological parameters, causing several pathologies in red blood cells, as well as changes in their quantitative composition. The proportion of pathologically changed blood cells increases under unfavourable living conditions (Alkindi et al., 1996; Çavaș \& ErgeneGözükara, 2003). Morphological changes in the formed elements can always be found in the fish blood on the background of various pathologies, diseases and poisoning. Thus, the results of the research demonstrate the negative effect of $\mathrm{Mn}$ and $\mathrm{Pb}$ on red blood cells, in particular their shape. Poikilocytosis was recorded in some cells, which may indicate signs of anemia caused by inhibition of erythropoiesis. Pathological changes in blood cells have the nature of a response against the background of the general toxic effect of heavy metals on the body. We have found that the reaction to $\mathrm{Ni}$ was opposite to the reaction to $\mathrm{PB}$ and $\mathrm{Mn}$, which was expressed in a small number of cells with an irregular form. Most of the red blood cells had the same shape as the control ones. The influence of all the studied toxicants had a similar trend, which was expressed in a decrease in the area of red blood cells and their nucleus.

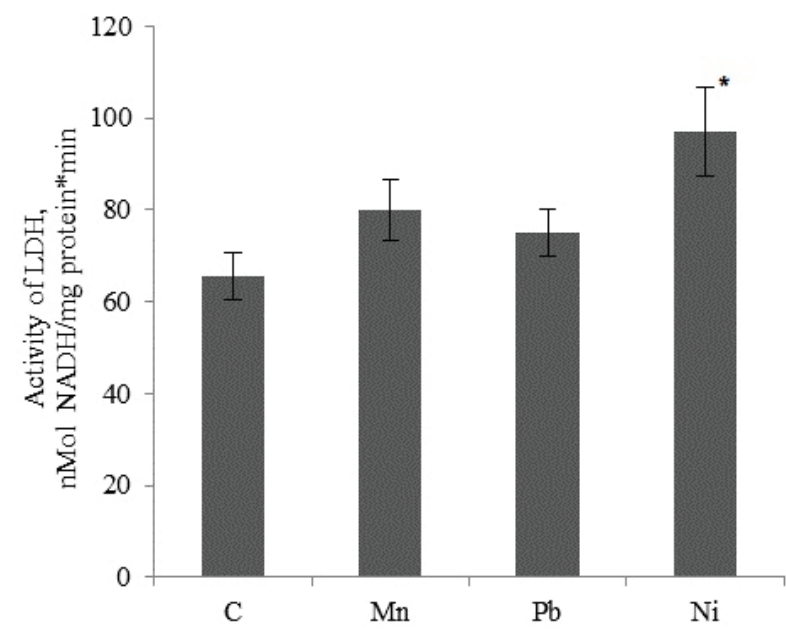

Fig. 5. Effect of heavy metals on lactate dehydrogenase activity in the stone moroko muscle tissues: * -indicates the significance of differences compared to the control $(\mathrm{P}<0.05), \mathrm{C}$ - control, $\mathrm{Mn}$ - manganese, $\mathrm{Pb}$ - lead, $\mathrm{Ni}$ - nickel; $\mathrm{X} \pm \mathrm{SE}$ 


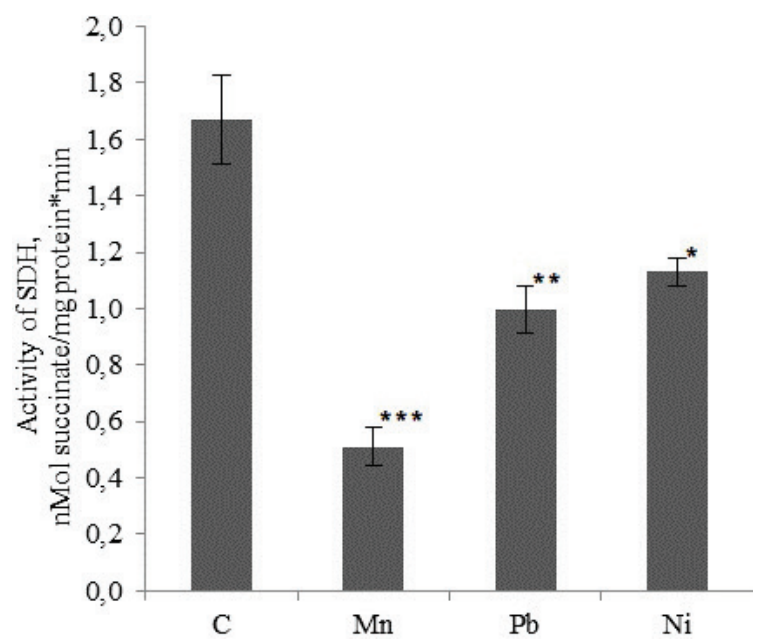

Fig. 6. Effect of heavy metals on succinate dehydrogenase activity in stone moroko muscle tissues: * indicates the significance of differences compared to the control $(\mathrm{P}<0.05)$, $* *$ indicates the significance of differences compared to the control $(\mathrm{P}<0.01),{ }^{* * *}$ indicates the significance of differences compared to the control ( $\mathrm{P}<0.001)$; $\mathrm{C}$ - control, $\mathrm{Mn}$ - manganese, $\mathrm{Pb}$ - lead, $\mathrm{Ni}$ - nickel, $\mathrm{x} \pm \mathrm{SE}$

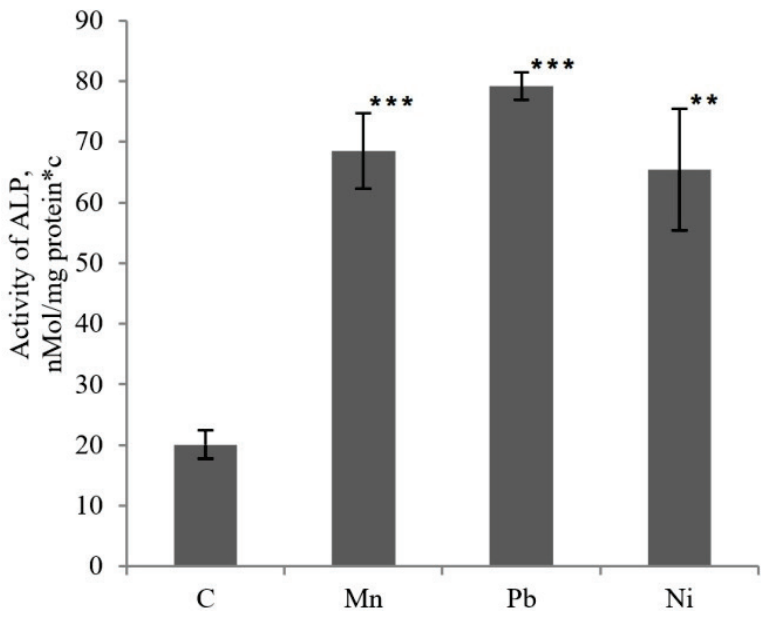

Fig. 7. Effect of heavy metals on alkaline phosphatase activity in stone moroko muscle tissues: ** indicates the significance of differences compared to the control $(\mathrm{P}<0.01)$, *** indicates the significance of differences compared to the control $(\mathrm{P}<0.001)$; $\mathrm{C}$ - control, $\mathrm{Mn}$ - manganese, $\mathrm{Pb}$ - lead, $\mathrm{Ni}$ - nickel; $\mathrm{x} \pm \mathrm{SE}$

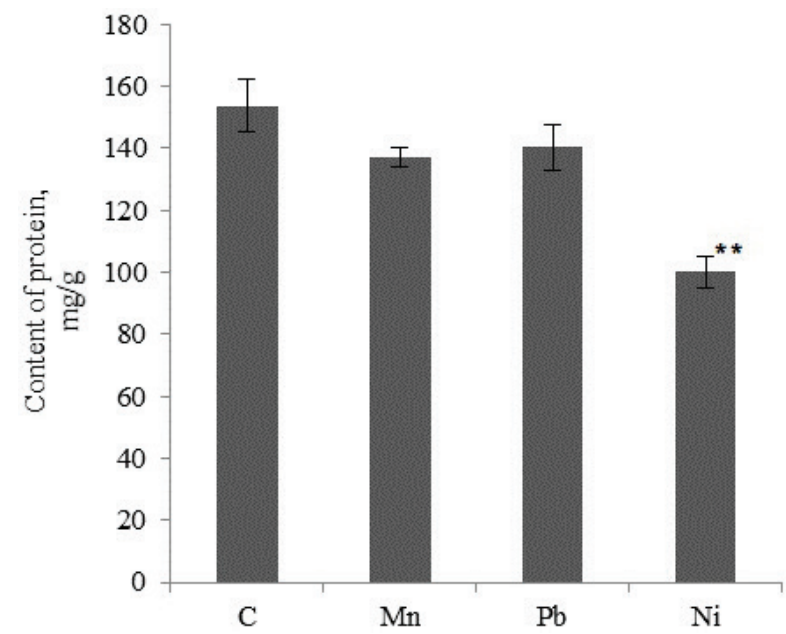

Fig. 8. The effect of heavy metals on the protein content in the muscles of the stone moroko: $* *$ indicates the significance $(\mathrm{P}<0.01)$ of differences compared to the control; $\mathrm{C}$ - control, $\mathrm{Mn}-$ manganese, $\mathrm{Pb}$ - lead, $\mathrm{Ni}-$ nickel; $\mathrm{x} \pm \mathrm{SE}$
It was found that the studied metals had a significant effect on white blood cells. This, in particular, manifested in the increase in their number. Leukocytosis may indicate pathologies associated with inflammatory processes, the immune system response to foreign substances, and disorders of the hematopoietic organs. It is known that metals dissolved in water can change the physiological parameters and biochemical parameters in the fish blood and tissues. The change in red blood cells involves a compensatory response to a decrease in the respiratory surface of the gills (tissue damage and cell proliferation) to support the transfer of oxygen from water to tissue, allowing the fish to survive during the shock phase.

Aquatic organisms accumulate $\mathrm{Pb}$ with water and food. $\mathrm{Pb}$ accumulates in various fish organs, such as the liver, spleen, and kidneys, as well as in the digestive system and gills (Jezierska \& Witeska, 2006). Typical symptoms of $\mathrm{Pb}$ poisoning include changes in blood parameters with acute damage to red and white blood cells (leukocytes). These changes harm the nervous system (El-Badawi, 2005). This study on Clarias gariepinus, exposed to $\mathrm{Pb}$ showed a significant reduction in their red blood cells (Ikeogu et al., 2004). Cases are also known of the frequency of morphological abnormalities in red blood cells (Witeska et al., 2010).

According to the results of the model experiment, the following has been found: an increase in the concentration of metals in water causes the accumulation of these metals in the organs and tissues of the stone moroko fingerlings; it causes pathological changes in fish blood cells; it leads to pathological changes in red blood cells: poikilocytosis, displacement of nucleus, leukocytosis.

Analyzing the data obtained, we can say that the action of toxic substances, in whichever way, causes disorders and certain changes in blood cells because the blood quickly responds to any irritations: deterioration of the hydrochemical regime, chemical contamination, penetration of pathogens. The liver of fish has an extremely wide functional and metabolic profile, bearing the main load under extreme conditions. With increased anthropogenic pressure, the ability of an organism to survive depends on its functional activity, so the analysis of the state of this organ can be used to determine the quality of habitat conditions. The hepatocytes on histological specimens of the liver of the stone moroko exposed to $\mathrm{Ni}$ and $\mathrm{Mn}$ ions did not have clearly defined boundaries, there was a large number of destroyed cells, which indicates the toxic effect of these heavy metals (Bhuyan \& Kavitha, 2014). Thus, histopathological analysis of hepatopancreas tissues of the experimental fish showed that the toxic effect of heavy metal concentrations, which are typical for the basin of Dnipro (Zaporizhzhia) Reservoir, caused changes in the structure of hepatocytes of the stone moroko, which is an adventitious species.

The use of several physiological and biochemical indicators makes it possible to assess the features of the course of metabolic processes in hydrobionts from their established range in the process of their adaptation to new living conditions. Violation of vital functions in hydrobionts living in altered conditions occurs at the biochemical level. These changes show the influence of environmental factors and allow assessment and diagnosis of the state of the ecosystem. The physiological and biochemical state of hydrobionts based on the determination of enzymatic activity allows one to establish the presence of stress reactions under unfavourable environmental conditions. One of these indicators can be enzymes of energy and phosphorus metabolism, which are well-established as test indicators for assessing the physiological state of living organisms. During our research, we have revealed an increase in lactate dehydrogenase activity in the muscle tissue of the stone moroko. This enzyme controls the conversion of lactate to pyruvate and is associated with the metabolic activity of cells. The increased activity of the enzyme is primarily associated with an increase in glycolytic processes in the muscle tissue of the studied fish. Lactate dehydrogenase is an enzyme that is present in most tissues of various animal taxa. It is involved in the conversion of lactate to pyruvate and vice versa. Changes in the activity of this enzyme are widely used as an indicator of stress (Almeida et al., 2002). In contrast, we have found changes in succinate dehydrogenase (SDH) activity. SDH is one of the important oxidative enzymes in the tricarboxylic acid cycle (TCA cycle) (James et al., 1992; Indra et al., 1999). According to Banaee \& Ahmadi (2011), the exposure of Astacus leptotactylus to organic toxicants also led to a decrease in SDH activity (Branch, 2011). Inhibition of SDH activity in stone moroko indicates a deterioration in the oxidative metabolic cycle 
and, as a result, the involvement of glycolysis in energy metabolism. It is known that the organism absorbs heavy metals, which further contributes to tissue damage and causes dysfunction of specific organs. This leads to changes in the activity of enzymes. First of all, this applies to enzymes involved in the regulation of energy metabolism. These changes may have triggered a violation of aerobic redox processes in the muscle tissues of stone moroko (More et al., 2005). This is indicated by a significant increase in LDH in muscle tissues, which may imply a temporary transition of the studied individuals from the state of aerobiosis to anaerobiosis. We have revealed changes in the activity of alkaline phosphatase in muscle tissues. Alkaline phosphatase is an enzyme involved in phosphate hydrolysis and membrane transport and is also used as an indicator of stress in biological systems. Changes in the activity of this enzyme indicate certain disorders in the cell membranes (Nemova, 2010; Ivanov et al., 2011). It is known that in ecotoxicological studies, alkaline phosphatase is used as a bioindicator for heavy metal toxicity (Mora et al., 2004). A change in the activity of the enzyme under the influence of $\mathrm{Pb}$ may indicate a decrease in the functional activity of this organ during intoxication with this heavy metal since it has a cumulative effect. Its action could cause a decrease in the synthesis of molecules of this enzyme (Molina et al. 2005). In addition, it can disrupt the structure and permeability of cellular organelles and cause acidosis (Nchumbeni et al., 2007) (exposure to $\mathrm{Ni}$ and $\mathrm{Mn}$ caused the opposite pattern of changes in the activity of this enzyme). This could lead to increased phosphorylation processes to ensure the normal process of cell growth and proliferation under conditions of their intoxication (Anderson et al., 2002). Changes in the activity of enzymes became the basis for significant changes in the physiological state. Changes in total protein in muscle tissue were also found, in particular, due to the impact of Mn and Ni. Protein as an alternative energy source in extremely difficult situations may also indicate a decrease in protein synthesis (Ragamanikam \& Mumuswamy, 2008). Changes in muscle protein content indicate general metabolic trends, in particular an increase in the free amino acids pool. This indicates an increase in catabolic processes and the breakdown of proteins as an energy source or their use in stress shielding of the body (Almeida et al., 2001). A significant decrease in protein due to the action of $\mathrm{Ni}$ may also be associated with significant hydration of this tissue due to depletion of the body when existing under extremely difficult toxicological conditions (Vinodhini \& Narayanan, 2009).

\section{Conclusion}

During the research, the adaptive capabilities of the adventitious species, stone moroko, to anthropogenic factors of the aquatic environment were studied. The research results have shown that with short-term exposure of stone moroko fingerlings to the studied contaminants, significant changes in morphological, histological and biochemical parameters occur. First of all, the toxic effect of heavy metals was manifested on linear and mass indicators. In addition, heavy metals significantly affected the morphometry of red blood cells, which consisted in changes in their mass, diameter, and shape, as well as in the percentage of pathologies (poikilocytosis, red blood cells with processes, displacement of red blood cell nuclei, leukocytosis). Toxicity caused a large number of destroyed cells in liver tissues. In general, at the initial stages, the stone moroko has an adaptive-compensatory reaction aimed at overcoming the toxic effects of metals, and subsequently, irreversible changes occur, in particular the onset of pathological processes. Chronic exposure to toxicants causes changes in the activity of enzymes. Thus glycolysis processes are enhanced due to an increase in lactate dehydrogenase activity. In contrast, aerobic redox processes were inhibited due to the inhibition of succinate dehydrogenase activity. Toxic effects caused an increase in the activity of alkaline phosphatase, which indicates an active increase in phosphorylation processes in muscle tissues, as well as an increase in their functional activity against heavy metals. So, the organism of stone moroko demonstrates several adaptive reactions aimed at strengthening protective processes against the harmful effects of heavy metals, ranging from reflex reactions, ending with changes in the activity of several enzymes.

The results obtained confirm the importance of studying the adaptation of fish to toxic loads, and changes in the studied indicators can be used as criteria for assessing the level of pollution in freshwater ecosystems.

\section{References}

Alkindi, A. Y. A., Brown, J. A., Waring, C. P., \& Collins, J. E. (1996). Endocrine, osmoregulatory, respiratory and haematological parameters in flounder exposed to the water soluble fraction of crude oil. Journal of Fish Biology, 49(6), 1291-1305.

Almeida, J. A., Diniz, Y. S., Marques, S. F. G., Faine, L. A., Ribas, B. O., Burneiko, R. C., \& Novelli, E. L. B. (2002). The use of the oxidative stress responses as biomarkers in Nile tilapia (Oreochromis niloticus) exposed to in vivo cadmium contamination. Environment International, 27(8), 673-679.

Almeida, J. A., Novelli, E. L. B., Dal-Pai Silva, M., \& Alves-Junior, R. (2001). Environmental cadmium exposure and metabolic responses of the Nile tilapia Oreochromis niloticus. Environmental Pollution, 114, 169-175.

Andersson, T., Forlin, L., Hardig, J., \& Larsson, A. (2002). A physiological disturbances in fish living in coastal water polluted with bleached Kraft pulp mill effluents. Canadian Journal of Fisheries and Aquatic Sciences, 45, 1525-1536.

Banae, M., \& Ahmadi, K. (2011). Sub-lethal toxicity impacts of endosulfan on some biochemical parameters of the freshwater crayfish (Astacus leptotactylus). Research Journal of Environmental Sciences, 5(11), 827-835.

Bhuyan, G., Anandhan, R., \& Kavitha, V. (2014). Qualitative and quantitative analysis of fish tissue of Oreochromis mossambicus collected from Kedilam River, Cuddalore, Tamilnadu, India. International Journal of Applied Sciences and Biotechnology, 2(2), 135-141.

Branch, T. N. (2011). Sub-lethal toxicity impacts of endosulfan on some biochemical parameters of the freshwater crayfish (Astacus leptodactylus). Research Journal of Environmental Sciences, 5(11), 827-835.

Britton, J. (2005). Dispersal of the invasive topmouth gudgeon, Pseudorasbora parva in the UK: A vector for an emergent infectious disease. Fisheries Management and Ecology, 12, 411-414.

Çavaş, T., \& Ergene-Gözükara, S. (2003). Evaluation of the genotoxic potential of lambda-cyhalothrin using nuclear and nucleolar biomarkers on fish cells. Mutation Research, Genetic Toxicology and Environmental Mutagenesis, 534, 93-99.

Copp, G. H., Vilizzi, L., \& Gozlan, R. E. (2010). Fish movements: The introduction pathway for topmouth gudgeon Pseudorasbora parva and other non-native fishes in the UK. Aquatic Conservation: Marine and Freshwater Ecosystems, 20(3), 269-273.

Davydov, O. N., Temnikhanov, Y. D., \& Kurovskaya, L. Y. (2006). Patologiya krovi ryb [Pathology of fish blood]. Incos, Kyiv (in Ukrainian).

Demirak, A., Yilmaz, F., Levent-Tuna, A., \& Ozdemir, N. (2006). Heavy metals in water, sediment and tissues of Leuciscus cephlaus from a stream in SouthWestern Turkey. Chemosphere, 63, 1451-1458.

Eschenko, N. D., \& Volskiy, H. H. (1982). Opredeleniye aktivnosti suktsinatdegidrogenazy [Determination of succinate dehydrogenase activity]. In: Prokhorova, M. I. (Ed). Metody biokhimicheskikh issledovaniy (lipidnyy i energeticheskiy obmen) [Biochemical research methods (lipid and energy metabolism)]. Publishing House of Leningrad University, Leningrad. Pp. 210-212 (in Russian).

Fánge, R. (1992). 1 Fish Blood Cells. In: Hoar, W. S. (Ed.). Fish Physiology, 12(B), 1-54.

Farombi, E. O., Adelowo, O. A., \& Ajimoko, Y. R. (2007). Biomarkers of oxidative stress and heavy metals levels as indicators of environmental pollution in African catfish (Clarias gariepinus) from Ogun River. International Journal of Environmental Research and Public Health, 4(2), 158-165.

Hardouin, E. A., Andreou, D., Zhao, Y., Chevret, P., Fletcher, D. H., Britton, J. R., \& Gozlan, R. E. (2018). Reconciling the biogeography of an invader through recent and historic genetic patterns: The case of topmouth gudgeon Pseudorasbora parva. Biological Invasions, 20(8), 2157-2171.

Ikeogu, C. F., Nsofor, C. I., Igwilo, I. O., \& Ngene, A. A. (2004). Haematological and serological responses of Clarias gariepinus to sublethal concentrations of lead nitrate. Bulletin of Environmental Contamination and Toxicology, 73, 911-918.

Indra, N., Karpagaganapathy, P. R., \& Meenakshi, V. (1999). Succinic dehydrogenase activity in tissues of male tree frog Polypedates maculatus (gray) exposed to median lethal dose of phosphamidon. Environment and Ecology, $17(1), 14-17$.

Ivanova, N. T. (1983). Atlas krovi ryb [Atlas of fish blood cells]. Legkaya i pishchevaya promyshlennost', Moscow (in Russian).

James, R., Sampath, K., \& Ponmani, K. P. (1992). Effect of metal mixtures on activity of two respiratory enzymes and their recovery in Oreochromis mossambicus (Peters). Indian Journal of Experimental Biology, 30(6), 496-499.

Jezierska, B., \& Witeska, M. (2006). The metal uptake and accumulation in fish living in polluted waters. In: Twardowska, I. (Ed.). Soil and Water Pollution Monitoring, Protection and Remediation. Dordrecht, Springer. Pp. 3-23.

Kovalenko, Y. O., Potrokhov, O. S., \& Prychepa, M. V. (2021). Features of physiological-biochemical reactions of stone moroko Pseudorasbora parva and european bitterling Rhodeus amarus to phenol. Hydrobiological Journal, 57(5), 89-98. 
Lowry, J. O. H., Rosenbrough, N. J., Farr, A. L., \& Randoll, R. J. (1951). Protein measurement with the Folin phenol reagent. Journal of Biological Chemistry, 193(1), 265-275.

Molina, R., Moreno, I., Pichardo, S., Jos, A., Moyano, R., Monterde, J. G., \& Cameán, A. (2005). Acid and alkaline phosphatase activities and pathological changes induced in Tilapia fish (Oreochromis sp.) exposed subchronically to microcystins from toxic cyanobacterial blooms under laboratory conditions. Toxicon, 46, 725-735.

Mora, S. D., Sheikholeslami, M. R., Wyse, E., Azemard, S., \& Cassi, R. (2004). An assessment of metal contamination in coastal sediments of the Caspian Sea. Marine Pollution Bulletin, 48, 61-77.

More, T. G., Rajput, R. A., \& Bandela, N. N. (2005). Effect of heavy metals on enzyme succinic dehydrogenage of fresh water bivalve, Lamellideans marginalis. Pollution Research, 24(3), 675.

National Research Council (2011). Guide for the care and use of laboratory animals. National Academy Press, Washington.

Nchumbeni, H., Davoodi, R., Kulkarni, B. G., \& Chavan, B. (2007). Effect of arsenic on the enzymes of the rohu carp, Labeo rohita (Hamilton, 1822). The Raffles Bulletin of Zoology Supplement, 14, 17-19.

Pollux, B. J. A., \& Korosi, A. (2006). On the occurrence of the Asiatic cyprinid Pseudorasbora parva in the Netherlands. Journal of Fish Biology, 69(5), 1575-1580.
Ragamanikam, V., \& Mumuswamy, N. (2008). Effect of heavy metals induced toxicity on metabolic biomarkers in common carp (Cyprinus carpio L.). Maejo International Journal of Sciences and Technology, 2, 192-200.

Sfakianakis, D. G., Renieri, E., Kentouri, M., \& Tsatsakis, A. M. (2015). Effect of heavy metals on fish larvae deformities: A review. Environmental Research, $137,246-255$.

Sharamok, T., Ananieva, T., \& Fedonenko, O. (2017). Environmental status of Kam'yanske reservoir (Ukraine). Ekológia, 36(3), 281-289.

Vinodhini, R., \& Narayanan, M. (2009). The impact of toxic heavy metals on the hematological parameters in common carp (Cyprinus carpio L.). Journal of Environmental Health Science and Engineering, 6(1), 23-28.

Witeska, M., Kondera, E., Szymańska, M., \& Ostrysz, M. (2010). Hematological Changes in common carp (Cyprinus carpio L.) after short-term lead ( $\mathrm{Pb})$ exposure. Polish Journal of Environmental Studies, 19(4), 825-831.

Záhorská, E., \& Kováč, V. (2009). Reproductive parameters of invasive topmouth gudgeon Pseudorasbora parva (Temminck and Schlegel, 1846) from Slovakia. Journal of Applied Ichthyology, 25(4), 466-469.

Zhiteneva, L. D., Poltavtseva, T. G., \& Rudnitskaya, O. (1989). Atlas normalnykh i patologicheski izmenennykh kletok ryb [Atlas of normal and pathologically altered fish blood cells]. Rostov Book Publishment, Rostov (in Russian). 